\title{
Bioluminescence in Insect
}

\author{
I. Yimjenjang Longkumer and Ram Kumar* \\ Department of Entomology, Dr. Rajendra Prasad Central Agricultural University, \\ Pusa, Bihar-848125, India \\ *Corresponding author
}

\section{A B S T R A C T}

Keywords

Fireflies,

Bioluminescence,

Luciferin

Article Info

Accepted:

04 February 2018

Available Online:

10 March 2018
Bioluminescence is defined as the emission of light from a living organism that performs some biological function. Bioluminescence is one of the oldest fields of scientific study almost dating from the first written records of the ancient Greeks. This article describes the investigations of insect luminescence and the crucial role imparted in the activities of insect. Many facets of this field are easily accessible for investigation without need for advanced technology and so, within the History of Science, investigations of bioluminescence played a significant role in the establishment of the scientific method, and also were among the many visual phenomena to be accounted for in developing a theory of light.

\section{Introduction}

When a living organism produces and emits light as a result of a chemical reaction, the process is known as Bioluminescence - bio means 'living' in Greek while 'lumen means 'light' in Latin. During the process, chemical energy is converted into light energy.

The process is caused by an enzyme-catalyzed chemolumine scence reaction. Bio luminescence is a product of a chemical reaction in an organism, It involves a class of chemicals called luciferins ("light bringers"). The luciferin oxidizes in the presence of a catalytic enzyme (luciferase) to create light and an ineffective compound (oxyluciferin).
Bioluminescence (BL) serves various purposes, including sexual attraction and courtship, predation and defense (Hastings and Wilson, 1976). This process is suggested to have arisen after $\mathrm{O}_{2}$ appearance on Earth at least 30 different times during evolution, as reflected by the existence of several luciferin/luciferase systems leading to different patterns of light emission i.e. color, intensity, timing, etc (Hastings, 1983). Bioluminescence has possibly evolved from early ultra-weak chemiluminescent oxidasecatalysed reactions to become very efficient functional light-emitting processes (quantumyield of BL of fireflies=0.88) (Seliger, 1975; Viviani and Bechara, 1996). A primal function in $\mathrm{O}_{2}$ detoxification, coupled with 
evolutionary advantages offered by specific light communication, may have allowed these species to prosper.

\section{Bioluminescence Origin}

The Greeks and Romans were the first to report the characteristics of luminous organisms. Aristotle (384-322 BC) described 180 marine species and was the first to recognize "cold light." The Greeks also made reference to sea phosphorescence (about 500 BC) (Harvey, 1957). The first book devoted to bioluminescence and chemilumine scence was published in 1555 by Conrad Gesner (1555; Carter and Kricka, 1982; Harvey, 1957).

Later in $19^{\text {th }}$ century Raphael Dubois performed a significant experiment where he extracted the two key components of a bioluminescent reaction and was able to generate light. $\mathrm{He}$ coined the terms "luciferine" and the heat labile "luciferase". The first luciferin was isolated in 1956 (Green and McElroy, 1956a).

\section{Structure of luciferin}

Luciferins (from the Latin lucifer, "lightbringer") are a class of light emitting heterocyclic compounds found in organisms that cause bioluminescence.

Luciferins are a class of smallmolecule substrates that are oxidized in the presence of the enzyme luciferase to produce oxyluciferin and energy in the form of light. It is not known just how many types of luciferins there are, but some of the better-studied compounds are listed below. There are many types of luciferins, yet all share the use of reactive oxygen species to emit light.

Snail: Latialuciferin is, in terms of chemistry, (E)-2-methyl-4-(2, 6, 6-trimethyl-1-cyclohex$1-y l)-1-b u t e n-1-o l$ formate and is from the freshwater snail Latianeritoides. Firefly luciferin is the luciferin found in many Lampyridae species. It is the substrate of luciferase responsible for the characteristic yellow light emission from fireflies.

Bacterial luciferin is a type of luciferin found in bacteria, some of which live within the specialized tissues of some squid and fish. The molecule contains a reduced riboflavin phosphate (Green and McElroy, 1956b).

Coelenterazine is found in radiolarians, ctenophores, cnidarians, squid, brittle stars, copepods, chaetognaths, fish, and shrimp. It is the prosthetic group in the protein aequorin responsible for the blue light emission.

Dinoflagellate luciferin is a chlorophyll derivative (i.e. a tetrapyrrole) and is found in some dinoflagellates, which are often responsible for the phenomenon of night time glowing waves (historically this was called phosphorescence, but is a misleading term).

A very similar type of luciferin is found in some types of euphausiid shrimp (Shimomura and Johnson, 1975). Vargulin is found in certain ostracods and deep-sea fish, to be specific, Poricthys. Like the compound coelenterazine, it is an imidazopyrazinone and emits primarily blue light in the animals.

Luciferin oxidation (typical for fireflies) with oxygen under luciferase catalysis in the presence of $\mathrm{Mg}^{2+}$ salts and ATP. In the first phase, luciferin reacts with oxygen under ATP consumption, $\mathrm{Mg}^{2+}$ assistance and luciferase catalysis to yield a reactive, highly unstable intermediate Int1. This intermediate is decomposing in the second stage into carbon dioxide and intermediate Int 2 in excited state (Phase 2). Int2 undergoes de-excitation by emission of a photon with a characteristic wavelength (Phase 3). In case of luciferin, the emission maximum is at $550-570 \mathrm{~nm}$. 


\section{Diversity of bioluminescence in insects}

Luminescence in terrestrial arthropods is found in Myriapoda and more extensively in insects (Herring, 1987). Recently, luminescence was also reported in Amazonian species of Blattodea (Zompro and Fritzsche, 1999).

\section{Coleoptera (beetles)}

The beetles have the largest number and variety of luminescent species. They are found mainly in the superfamily Elateroidea (former Cantharoidea and Elateroidea), which includes fireflies (Lampyridae), railroad worms (Phengodidae), click beetles (Elateridae), and related families.

Luminescence has also been found in a luminescent larva of Xantholinusin the Staphylinidae (Costa et al., 1986) and larvae and adults of an undetermined species.

Fireflies emit green-yellow flashes characterized by duration, interval, and frequency from ventral lanterns for sexualattraction purposes (Lloyd, 1971; Seliger, 1964; Viviani, 2001).

Click beetles have two dorsal prothoracic lanterns, which usually emit continuous green light, and a ventral abdominal light organ that emits continuous green-orange light when the insect is flying.

Railroad worms emit the widest range of colors among luminescent beetles, including some of the most spectacular examples with larvae and females having rows of lateral lanterns along the body emitting green-orange light and, in addition, South-American species with cephalic lanterns emitting from yellowgreen to red light depending on the species. In the larval stage, bioluminescence assumes mainly defensive functions but attraction of prey has also been reported in the larvae of the Brazilian Pyrearinuster mitilluminans click beetle, which display the phenomenon of luminous termite mounds (Bechara, 1988).

\section{Diptera}

In Diptera, luminescence is found in the Mycetophilidae. The best known are Arachnocampa species from New Zealand caves and the Australasian region (Meyer, 1990), whose larvae construct webs on the roof of caves. Other luminescent mycetophilids are found in the genera Keroplatus and Orfelia (Harvey, 1952). Orfelia fultoni is another web-building species, which occurs in stream banks of the Appalachian mountains of eastern USA (Fulton, 1941).

\section{Functions}

Larvae of Arachnocampa construct webs on the roof of caves and use their continuous blue-green luminescence to attract the flying insects on which they prey. Luminescence is produced at the terminal end of Malpighi tubules (Gatenby, 1959).

When a male lands on a female pupa she glows, and when she is ready to emerge, up to three males may be clinging to her. A mounted male has to fight off rivals that attempt to displace him. Newly emerged females use their light to attract males if none are present (Richards, 1960).

\section{Hemiptera}

Planthoppers in the family Fulgoridae (Hemiptera: Fulgoroidea; commonly called lanternflies) are bizarreand charismatic insects. Many fulgorid species are brilliantly colored, and some produce cuticular waxes comprised mostly of keto Esters (Mason et al., 1989). 


\section{Bioluminescent Colour Variation in Insect}

\begin{tabular}{|l|}
\hline Phengodids \\
\hline Arachnocampa \\
\hline Fulgora \\
\hline Photinus and Lampyris \\
\hline Phrixothrix \\
\hline
\end{tabular}

paired green lights on each segment and redlights at the end

blue green

White light.

Yellow-green in color $(520-650 \mathrm{~nm})$

Larval and adult female, thorax and abdomen produce green to orange light $(530-590 \mathrm{~nm})$. That on the head produces red light $(580 \mathrm{~nm}$ to over $700 \mathrm{~nm})$

\section{Structure of Luciferin}

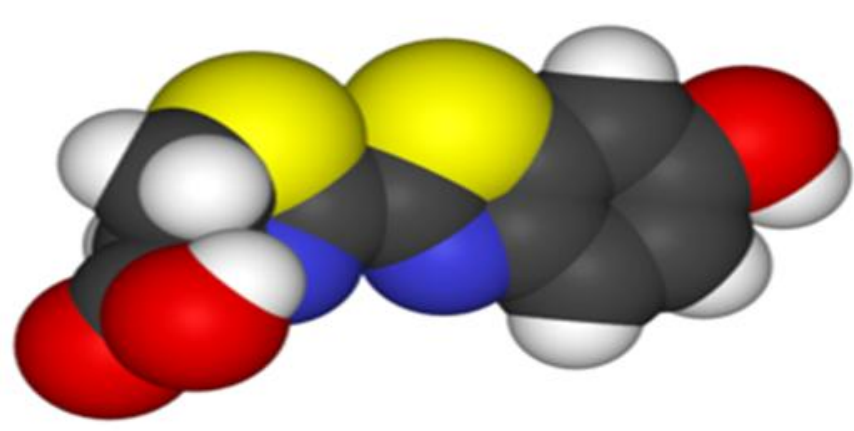<smiles>O=C(O)[C@@H]1CSC(c2nc3ccc(O)cc3s2)=N1</smiles>

Firefly Luciferin

Fig.1 Mechanism of luciferin bioluminescence

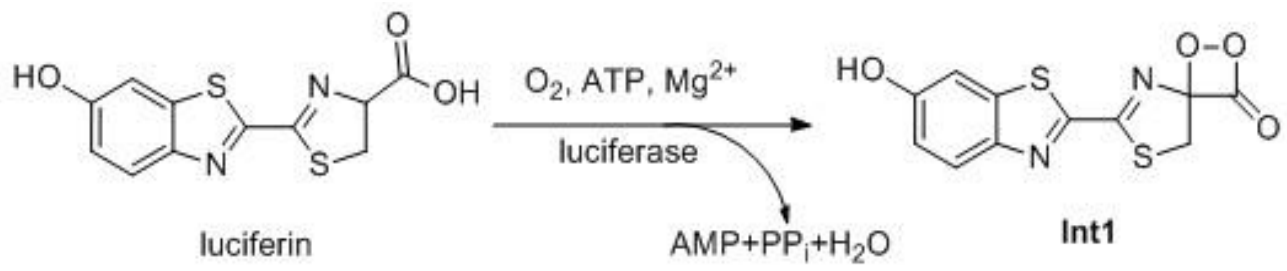<smiles>CC(C)CC(C)C(=O)OC12CSC(c3nc4ccc(O)cc4s3)=NC1(C(C)C)OO2</smiles>

Phase 2<smiles></smiles><smiles>O=C1CSC(c2nc3ccc(O)cc3s2)=N1</smiles> 
Fig.1-23 Light organs of various luminescent beetles, shown in black (James Lloyd, 1971)
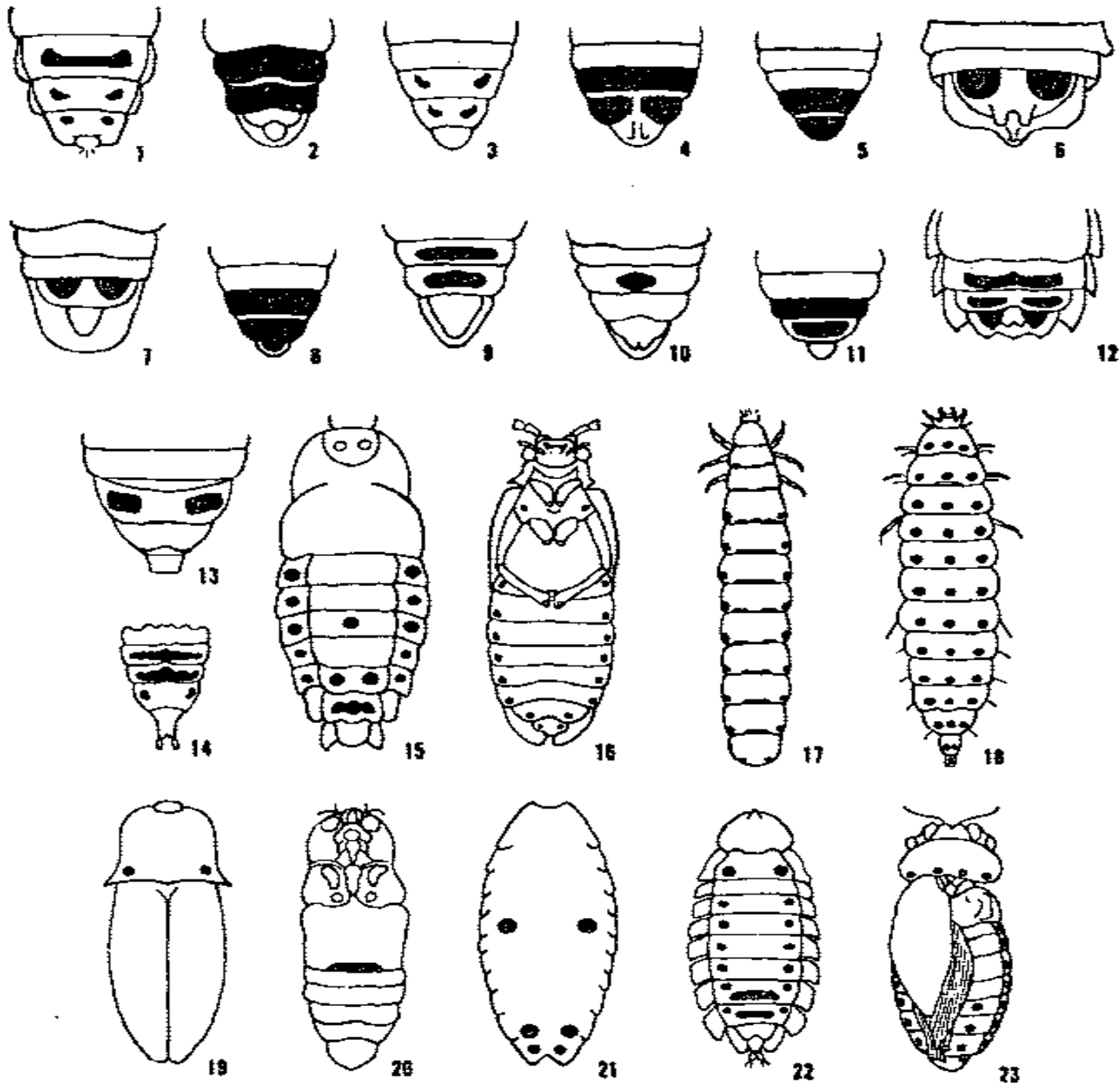

1. Lychnurisrofa, female. 2. Phctinusscintillans, male. 3. Pyractomenasp., female. 4. Luciola sp., male. 5. Luciolachinensis, male. 6. Callopisma sp., female. 7. Robopusmontanus, male. 8. Luciolacruciata, male. 9. Photuris sp., female. 10. Photinusreintillans, female. 11. Luciolalateralis, male. 12. Pleotomus sp., female. 13. Luciolaiusitanica, female. 14. Lampyrisnoctiluca, female. 15. Lamprohizasplendidula, female. 16. Harrnateliabilinea, male. 17. Phengodes sp., female. 18. Diplocladonhasselti, female. 19. Pyrophorus sp., male and female, dorsal. 20. Pyrophorus sp., male and female, ventral. 21. Phausisreticulata, female. 22. Lamprohizamulsanti, female. 23. Dioptomaadamsi, male. 


\section{Significance of bioluminescence in Insects}

In simple forms of life, bioluminescence is thought to have functional significance in many arthropods, the light from bioluminescence is used to lure the opposite sex for mating, or it may be used to attract prey, or for defense.

\section{Mating signal}

Light is known to act as a mating signal in fireflies. In certain species the bioluminescence attracts individuals of the same species to aggregate, thus indirectly improving the chances of mating. In some species of Lampyridae, the females are wingless and sedentary; light production is therefore important for them to attract the winged males. Flash patterns in bioluminescent insects vary between species and between sexes.

On a relatively cool night, some species wait 5.5 seconds then emit a single short flash. Other species may wait one second and then hold the flash for a full second. Some tropical species congregate in large numbers and flash in unison. Male and female fireflies of Photurispyralis emerge at dusk emitting a single short flash at regular intervals. The flashes are usually from male fireflies seeking mates. Males outnumber the females fifty to one. Females climb a blade of grass, flashing when males flash within 10-12 feet of the females. Exchange of signals is repeated 5 to 10 times until they start mating.

\section{Predation}

The most unique example of light acting as a lure for prey is found in the New Zealand glowworm fly, Arachnocampa luminosa. The female fly deposits eggs on the ceiling of dark caves. Upon hatching, the larvae hang down by a sticky thread and produce light. During night, the entire cave may glow with this light, attracting other insect species. These attracted insects get entangled in the sticky threads and are preyed upon by the larvae. The caves inhabited by flies are popularly known as 'luminous caves' and are tourist attraction spots in New Zealand.

\section{Defense}

In railroad worms the continuous glow of the head region when the larvae are walking, suggests a possible illumination function, whereas the circumstances under which the lateral light organs are switched on suggest a defense function. Sudden flashes can repel potential predators. The railroad worm larvae live at high densities, confined to small areas, and may use simultaneous emission to frighten potential enemies, or they may also use the light to intimate the mated females about to lay eggs about overcrowding and competition for food sources.

\section{Bioluminescence in pest management}

Bioluminescence is used as a tool for mapping organism distribution patterns. Recently, in 2001, scientists in USA have modified the genetic material of the pink bollworm, an insect pest of cotton, with green fluorescent protein (GFP) derived from the jelly fish, Aequora victoria. The GFP transgenic pink bollworm strain fluoresces strongly green when viewed in its larval stage. The objective of this research is twofold; the first is to develop a GFP marked strain of pink bollworm for field performance studies and to map the distribution of the pest.

It may also serve as an additional tool for field managers. Their future objective is to eventually add a temperature-sensitive lethal gene along with the GFP gene into the pink bollworm that could be used for its management (Babu and Kannan, 2002).

\section{References}

Babu, B. G. and Kannan, M. 2002. Lightning Bugs. Resonance. 49-55 pp.

Bechara E. J. H. 1988. Luminescent elaterid beetles: biochemical, biological and ecological aspects. Adv. Oxygen. Process, 1: 123-178. 
Carter, T. J. N. and Kricka, L. J. 1982. Luminescence: historic aspects. In Clinical and Biochemical Luminescence. L. J. Kricka, and T. J. N. Carter, editors. Marcel Dekker Inc, New York. 2-5.

Costa, C., Vanin S. and Colepicolo P. N. 1986. Larvae of Neotropical Coleoptera XIV: first record of bioluminescence in the family Staphylinidae (Xantholini). Rev. Bras. Entomol., 30: 101-104.

Fulton B. B. 1941. A luminous fly larva with spider traits. Ann. Entomol. Soc. Am., 34: 289-302.

Gatenby J. B. 1959. Notes on the New Zealand glowworm Bolitophila luminosa (Arachnocampa luminosa) Trans. R.Soc. N. Z., 88: 149-156.

Green, A. and McElroy, W.D. 1956b. "Function of adenosine triphosphate in the activation of luciferin". Arch. Biochem. Biophys., 64 (2): 257-71.

Green, A.A. and McElroy, W.D. 1956a. Crystalline firefly luciferase. Biochim. Biophys. Acta., 20: 170-176.

Harvey E. N. 1952. Bioluminescence. Academic Press, New York.

Harvey, E.N. 1957. A history of luminescence from the earliest times until 1900. Vol 44. The American Philosophical Society, Philadelphia.

Hastings, J.W. 1983. Biological diversity, chemical mechanisms and evolutionary origins of bioluminescent systems., $J$. Mol. Evol., 19, 309-321.

Hastings, J.W. and Wilson, T. 1976. Bioluminescence and chemiluminescence. Photochem. Photobiol., 23, 461-473.

Herring P. J. 1987. Systematic distribution of bioluminescence in living organisms. $J$. Biolum. Chemilum., 1: 147-163.
Lloyd J. E. 1971. Bioluminescent communication in insects. Am. Rev. Entomol., 38: 97-122.

Meyer-Rochow V. B. 1990. The New Zealand Glow-Worm. Waitomo Caves Museum Society, Waitomo Caves, New Zealand.

Richards, A. M. 1960. Observations on the New Zealand glowworm Arachnocampa luminosa (Skuse) 1 890. Trans. R. Soc. N. Z. 88:559-74

Seliger, H. H., Buck, J. B., Fastie, W. G. and McElroy W. D. 1964. The spectral distribution of firefly light. J. Gen. Physiol., 48: 95-104.

Seliger, H.H. 1975. The origin of bioluminescence. Photochem. Photobiol., 21, 355-361.

Shimomura, O., Johnson, F.H. 1975. Chemical nature of bioluminescence systems in coelenterates. Proc. Natl. Acad. Sci. U.S.A. 72 (4): 1546-49.

Viviani V. R. 2001. Fireflies (Coleoptera: Lampyridae) from southeastern Brazil: habitats, life history, and bioluminescence. Ann. Entomol. Soc. Am., 94: 129-145.

Viviani, V.R. and Bechara, E.J.H. 1996. Larval Tenebriomolitor

(Coleoptera: Tenebrionidae) fat body extracts catalyze firefly luciferin and ATP-dependent chemilumine scence: a luciferaselikeenzyme. Photochem. Photobiol., 63, 713-718.

Zompro, O. and Fritzsche, I. 1999. Lucihormetica fenestratan. gen., n.sp. The first record of luminescence in an orthopteroid insect (Dyctyoptera: Blaberidae: Blaberinae: Brachyolini). Amazoniana 15: 211-219.

\section{How to cite this article:}

Yimjenjang Longkumer, I. and Ram Kumar. 2018. Bioluminescence in Insect. Int.J.Curr.Microbiol.App.Sci. 7(03): 187-193. doi: https://doi.org/10.20546/ijcmas.2018.703.022 